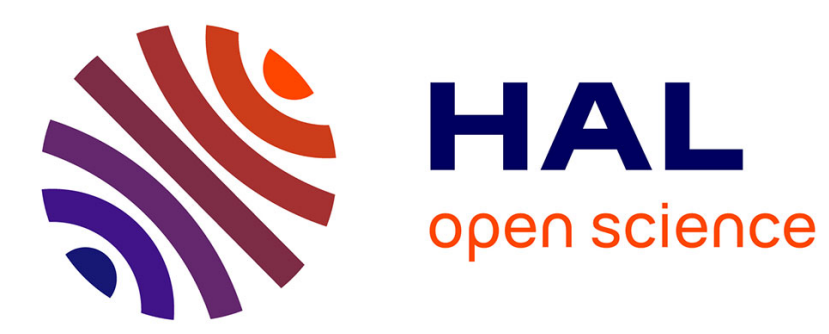

\title{
Thermomechanical behavior by martensitic transformation in single and polycrystals of metallic alloys
}

\author{
Etienne Patoor, André Ererhardt, Marcel Berveiller
}

\section{To cite this version:}

Etienne Patoor, André Ererhardt, Marcel Berveiller. Thermomechanical behavior by martensitic transformation in single and polycrystals of metallic alloys. Revue de Physique Appliquée, 1988, 23 (4), pp.702-702. 10.1051/rphysap:01988002304070200 . jpa-00245858

\section{HAL Id: jpa-00245858 https://hal.science/jpa-00245858}

Submitted on 1 Jan 1988

HAL is a multi-disciplinary open access archive for the deposit and dissemination of scientific research documents, whether they are published or not. The documents may come from teaching and research institutions in France or abroad, or from public or private research centers.
L'archive ouverte pluridisciplinaire HAL, est destinée au dépôt et à la diffusion de documents scientifiques de niveau recherche, publiés ou non, émanant des établissements d'enseignement et de recherche français ou étrangers, des laboratoires publics ou privés. 
Thermomechanical Behavior by Martensitic Transformation in Single and Polycrystals of Metallic Alloys Etienne PATOOR, André EBERHARIT, Marcel BERVEILLER L.P.M.M.-U.A. CNPS 1215

Institut Supérieur de Génie Mécanique et Productique Université de METZ, 57045 - METZ Cedex, France

The phenomenon of Transformation Plasticity is a narticular behavicr observed in some alloys when a phase transformation occurs under apolied stress. The kinematic study for the overall behavior may determine the strain induced by transformation and the strain caused by other mechanisms (e.g. motion of dislocations, thermal expansion ...). According to this distinction we recognize two classes of behavior $/ \overline{1} /$ :

- Counled Transformation Plasticity (C.T.P.) ${ }^{-}$in this case, characteristics of transformation are modified by the other mechanisms of deformation (e.g. in steels, martensitic transformation induces plastic flow in the narent phase and this plastic flow changes the transformation characteristics).

- Pure Transformation Plasticity (P.T.P.) where strain is exclusively produced by phase transformation.

In thermoelastic martensitic transformation, we observed a phenomenon called pseudoelasticity which is characterized by a large reversible inelastic strain (more than ten per cent for single crystal). This phenomenon may be considered as Pure Transformation plasticity and the aim of this work is to modell it $/ 2 \overline{7}$. In P.T.P. the mechanism of transformation is composed with a shear part on the habit plane, and an extension part in the direction of the normal to the habit plane as shown in Fig. 1. So for a single crystal, the inelastic strain can be defined by the following expression :

$$
\varepsilon_{i j}^{A M}=\frac{1}{2}\left(m_{i} n_{j}+m_{j} n_{i}\right) g=R_{i j} g
$$

where $g$ denotes the shear magnitude in the direction of motion and $R_{i j}$ is the orientation tensor of martensite variant.

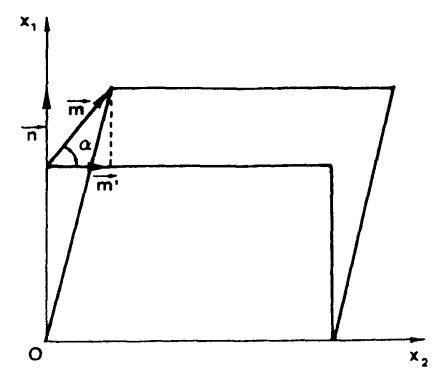

Fig. 1. Unit volume transformation from parent shase to martensite.

This result may be generalized for the case where many variants are formed and also for a polycrystal.

In the single crystal case, we deduced a relation between external parameters and internal variables from a thermomechanical approach based on the Gibbs free energy. This study enables to define a pseudoelastic potential and to obtain the transformation criterion, so we are in the case of standard material and the potential allows to define the single crystal flow rule. The change of Gibbs free energy is exoressed by :

$$
\Delta G=\Delta G^{C}(T) V_{M}+\Gamma S+E e_{\text {ext }}+E_{\text {int }}
$$

where $V_{M}$ is the volume of martensite. This relation is composed by four terms of different origins :
- $\Delta G^{C}(T)$ denotes the chemical free energy;

- $\Gamma$ denotes the free energy of interface;

- Eext is the interaction energy with externa1ly applied stress;

- Eint is the elastic energy associated with the inclusion.

$\Gamma$ may be neglected for thermoelastic martensite, $E_{\text {ext }}$ can be obtained by using Eshelby's relation $/ \overline{3} /$ and Eint was calculated by Fassi-Fehri et al. $\mid \overline{4} /$. So, we obtain the following expression for the potential :

$\frac{\Delta G}{V}=\Delta G^{c}(T)-\sigma{ }_{i j} g \sum_{n} R_{i j}^{n} F^{n}+g^{2} \sum_{n} E^{n} F^{n}+g^{2} \sum_{n, m} H^{n m} F^{n} F^{m}$

where $F^{n}$ denotes the volume fraction of variant $n$, $E^{n}$ denotes the interaction energy between variant $n$ and parent phase and $\mathrm{H}^{\mathrm{nm}}$ denotes the interaction matrix between the variants of martensite. So, for one variant, if we consider an inclusion with a plate shape $\left(E^{n}=0\right)$, the criterion which determines the beginning of the transformation is :

$$
\sigma_{i j} R_{i j}^{n}=\frac{\Delta G(T)}{g}
$$

This criterion is analogous to the Schmid one, but hydrostatic pressure is taken into account. Finally, the flow rule is expressed by :

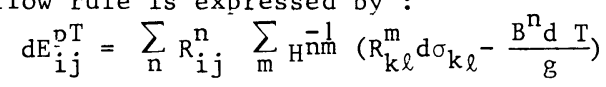

$B^{n}$ denotes the coefficient which express the linear relation between $\Delta G^{c}$ and temperature.

To modell pseudoelasticity in the polycrystal, we used a phenomenological approach based on a transformation criterion analogous to the Von Mises one :

$$
\sqrt{\mathrm{J}_{2}}+\frac{\operatorname{tg} \alpha}{3} \mathrm{I}_{1}-\frac{\Delta \mathrm{G}^{\mathrm{C}}(\mathrm{T})}{\mathrm{g} \cos \alpha}=0
$$

To obtain the flow rule, we consider that the polycristal is a standard material and so we obtain :

$$
\mathrm{dE}_{i j}^{\mathrm{pT}}=\mathrm{a}\left(\frac{\mathrm{s}_{\mathrm{ij}}}{2 \sqrt{\mathrm{J}_{2}}}+\frac{\mathrm{tg} \alpha}{3}\right)\left[\left(\frac{\mathrm{s}_{\mathrm{k} \ell}}{2 \sqrt{\mathrm{J}_{2}}}+\frac{\operatorname{tg} \alpha}{3}\right) \mathrm{d} \sigma_{k \ell^{-}} \frac{\mathrm{BdT}}{\mathrm{g} \cos \alpha}\right]
$$

where "a" denotes a function to be identified by a particular type of loading.

These flow rules are then compared with experimental results for uniaxial tension of a $\mathrm{Cu}-\mathrm{Zn}-\mathrm{Al}$ alloy We observed a good agreement between experiments and theoretical values for the transformation point and for the transformation slope $\underline{\underline{2}} \bar{T}$.

References

Lİ E. Patoor: Thèse de Docteur-Ingénieur, Université de Metz (1986)

$1 \overline{2} 7$ E. Patoor, A. Eberhardt and M. Berveiller:Potentiel pseudoélastique et plasticité de transformation martensitique dans les mono et polycristaux métalliques. To be published in Acta Met (1987).

$\mid \overline{3} \bar{j}$ J.D. Eshelby: Elastic inclusion and inhomogeneities, Prog. Solid Mech., 2 (1961) 89-140.

/4/ O. Fassi-Fehri, A. Hihi and M. Berveiller: An hardening theory in pseudoelastic single crystals To be published in Scripta Met. (1987) 